Jurnal Kesehatan Indonesia, Volume. IX, Nomor. 3, Juli 2019

\title{
Faktor-Faktor Yang Berhubungan Dengan Status Karies Gigi Pada Anak Sekolah Min 1 Kota Banjarmasin
}

\author{
Factors Realated To Dental Caries Status In Children At Min 1 City In Banjarmasin \\ Astannudinsyah ${ }^{1 *}$, Rizqi Aulia Ruwanda ${ }^{1}$, Abdul Basid ${ }^{1}$ \\ ${ }^{1}$ Program Studi Kesehatan Masyarakat STIKes Cahaya Bangsa Banjarmasin \\ Jl Achmad Yani Km 5,5 Kec. Martapura Timur - Kab. Banjar \\ *Korespondensi : astan.syah@gmail.com
}

\begin{abstract}
At the age of 10 and over, $71,2 \%$ of children experience dental caries. The prevalence of active caries in Kota Banjarmasin is $65 \%$. While in Puskesmas (Public health service) Kelayan Timur working area, 389 cases of dental caries found. Additionaly, the governement through Kemen-Kes RI (Indonesian Health Ministry) tergeting Indonesian society to be free from dental caries by 2030. Some factors influencing dental caries are dental health awareness and attitudes namely time and frequency of brushing teeth, cariogenic foods, and the method of brushing teeth. This study is aimed to reveal the correlation between knowledge factors as well as dental health attitudes and dental caries status. This is an anlytical study utilizing cross sectional. The sample of the study is students of MIN 1 Kota Banjarmasin in 2018 with the total of 53, taken by means of perposive sampling. Statistical testing used is chi-square with $95 \%$ of reliance degree.The result shows that there are correlations between dental health knowledge p-value 0,004, time and frequency of brushing teeth $p$-value 0,002, cariogenic foods $p$-value 0,018, as well as teeth brush method p-value 0,015 and dental caries occasion in MIN 1 Kota Banjarmasin. The dental caries status is affected by dental health knowledge and attitudes.
\end{abstract}

Keywords: dental, caries, factors.

\section{Pendahuluan}

Karies menjadi salah satu bukti tidak terawatnya kondisi gigi dan mulut masyarakat Indonesia. Masyarakat umumnya cenderung beranggapan bahwa gigi sulung tidak perlu dirawat karena akan diganti dengan gigi tetap(1). Mereka kurang paham bahwa jika gigi sulung tidak dipelihara dengan baik, maka akan berlubang. Adapun upaya untuk menunjang kesehatan yang optimal maka upaya dibidang kesehatan gigi perlu diperhatikan (2).

Karies gigi tetap menjadi masalah kesehatan masyarakat yang paling utama (3). World Health Organization menyatakan di seluruh dunia, $60-90 \%$ anak-anak sekolah memiliki gigi berlubang, sedangkan menurut data dari PDGI (Persatuan Dokter Gigi Indonesia) menyebutkan bahwa sedikitnya 89\% penderita karies adalah anak-anak. Sampai sekarang karies gigi merupakan masalah kesehatan baik di negara maju maupun negara-negara berkembang (4).

Hasil Survei Kesehatan Rumah Tangga (SKRT) menyebutkan bahwa penduduk Indonesia pada usia 10 tahun keatas, sebanyak $46 \%$ mengalami penyakit gusi dan $71,2 \%$ mengalami karies gigi, sedangkan kelompok usia 12 tahun, sebanyak 76,2\% mengalami karies gigi (5).

Riskesdas 2013 pervalensi karies di Indonesia sebesar $72,6 \%$ dan DMF-T $4,5 \%$, pervalensi karies di Indonesia jauh diatas target yang akan dicapai tahun 2020 yaitu $54,6 \%$. Lima provinsi dengan DMF-T tertinggi adalah: (1) Bangka Belitung 8,5\%, (2) Kalimantan Selatan $7,2 \%$, (3) Kalimantan Barat 6,2\%, (4) Sulawesi Selatan 6,6\%, (5) Daerah Istimewa Yogyakarta 5,9\%. Lima provinsi dengan pervalensi karies tertinggi adalah:
(1)
Bangka
Belitung
$88,1 \%$,

Kalimantan Selatan 86,9\%, (3) Sulawesi Selatan 83,3\%, (4) Kalimantan Barat 
$81,7 \%$, (5) Sulawesi Barat 81,6\%. Padahal, pemerintah melalui Kementerian Kesehatan RI menargetkan penduduk Indonesia bebas karies pada tahun 2030 (6).

Dampak karies gigi jika terlambat menemukan karies pada akhirnya gigi tidak bisa ditambal lagi maka gigi tersebut harus dicabut. Bila sesudah pencabutan, gigi tidak diganti dengan gigi palsu, maka gigi yang ada di kanan kirinya akan bergeser ke arah gigi yang baru dicabut, akibatnya gigi menjadi renggang, sisa-sisa makanan tersebut akan membusuk, menyebabkan bau mulut tidak sedap dan suasana mulut menjadi asam, banyak kuman yang mengakibatkan terjadinya kerusakan atau lubang pada gigi tersebut, dan dapat menyebabkan kerusakan pada gigi yang lain, untuk itu perlunya penangan masalah gigi sejak usia dini (7). Berdasarkan teori Blum, karies gigi depengaruhi oleh empat faktor penting yaitu lingkungan (fisik maupun sosial budaya), perilaku, pelayanan kesehatan dan keturunan. Dari empat faktor tersebut pengetahuan dan perilaku yang mempengaruhi dan memegang peranan penting dalam kebersihan gigi dan mulut secara langsung, meningkatkan pengetahun dengan memberikan pendidikan kesehatan gigi dan mulut dapat mempengaruhi perilaku dalam menjaga kesehatan gigi dan mulut. secara langsung, perilaku dapat juga mempengaruhi faktor lingkungan dan pelayanan kesehatan. Pengetahuan atau kognitif merupakan domain yang sangat penting dalam membentuk tindakan seseorang. Pengetahuan yang baik apabila tidak ditunjang dengan sikap positif yang diperlihatkan akan mempengaruhi seseorang untuk berperilaku. Perilaku merupakan faktor terbesar kedua setelah faktor lingkungan yang mempengaruhi kesehatan individu, kelompok atau masyarakat. Kesehatan merupakan hasil hasil interaksi berbagai faktor, baik faktor internal atau faktor dari dalam diri manusia maupun faktor eksternal atau faktor dari luar manusia. Perilaku manusia antara satu dengan yang lainnya tidak sama baik dengan kepandaian, bakat, sikap, minat maupun kepribadian (8).
Kebiasaan membersihkan gigi dan mulut sebagai bentuk perilaku yang didasari oleh pengetahuan akan mempengaruhi baik atau buruknya kebersihan gigi dan mulut, selanjutnya juga akan mempengaruhi angka karies gigi (9).

Belum diketahuinya gambaran pengetahuan kesehatan gigi dan perilaku pemeliharaan kesehatan gigi seperti frekuensi dan waktu sikat gigi, makanmakanan kariogenik, dan cara sikat gigi pada anak usia sekolah. Maka peneliti tertarik untuk mengetahu apa saja faktorfaktor yang berhubungan dengan status karies gigi.

\section{Metode Penelitian}

Penelitian ini merupakan penelitian observasional analitik dengan model pendekatan cross sectional (potong lintang) yaitu untuk melihat hubungan antara variabel indepeneden (pengetahuan kesehatan gigi, dan perilaku pemeliharaan kesehatan gigi, yaitu: frekuensi dan waktu sikat gigi, makan-makanan kariogenik, dan cara sikat gigi) dan variabel dependen (status karies gigi) diteliti sekaligus pada saat yang sama.

Populasi dalam penelitian ini adalah seluruh murid kelas IV dan V Madrasah Ibtidaiyah Negeri (MIN) 1 Kota Banjarmasin tahun 2018 berjumlah 112 orang. Teknik pengambilan sampel yang digunakan dengan purposive sampling dimana seluruh populasi dijadikan sampel, dengan jumlah responden sebanyak 53 murid.

Data primer yang terdiri dari variabel pengetahuan kesehatan gigi dan perilaku pemeliharaan kesehatan gigi, didapatkan dengan cara membagikan langsung lembar kuesioner kepada responden, untuk observasi cara sikat gigi dilakukan secara simulasi. Sedangkan variabel status karies gigi didapatkan dengan cara pemeriksaan gigi secara langsung. Analisis data menggunakan statistik univariat dan bivariat uji chi square menggunakan program SPSS dengan derajat kepercayaan $95 \%$ nilai $p$ value $<0,05$ 
Hasil Penelitian

Tabel 1. Karakteristik responden berdasar-kan jenis kelamin

\begin{tabular}{cccc}
\hline No & $\begin{array}{c}\text { Jenis } \\
\text { Kelamin }\end{array}$ & $\begin{array}{c}\text { Frekuensi } \\
\text { (n) }\end{array}$ & $\begin{array}{c}\text { Persentase } \\
\text { (\%) }\end{array}$ \\
\hline 1. & Laki-laki & 24 & 45,3 \\
2. & Perempuan & 29 & 54,7 \\
\hline & Total & 53 & 100,0 \\
\hline
\end{tabular}

Berdasarkan Tabel 1 dapat diketahui bahwa responden dalam penelitian ini sebagian besar berjenis kelamin perempuan yaitu sebanyak 29 responden (57\%). Sedangkan untuk responden berjenis kelamin laki-laki yaitu sebanyak 24 responden (45,3\%).

Tabel 2. Karakteristik responden berdasar-kan umur

\begin{tabular}{|c|c|c|c|}
\hline No & $\begin{array}{c}\text { Umur } \\
\text { Responden }\end{array}$ & $\begin{array}{l}\text { Frekuensi } \\
\text { (n) }\end{array}$ & $\begin{array}{c}\text { Persentase } \\
\text { (\%) }\end{array}$ \\
\hline 1. & $\begin{array}{l}9-10 \\
\text { tahun }\end{array}$ & 24 & 45,3 \\
\hline 2. & $\begin{array}{l}11-12 \\
\text { tahun }\end{array}$ & 29 & 54,7 \\
\hline & Total & 53 & 100,0 \\
\hline
\end{tabular}

Berdasarkan Tabel 2 dapat diketahui bahwa responden dalam penelitian ini yang berumur $9-10$ tahun sebanyak 24 responden (45,3\%) dan yang berumur $10-12$ tahun sebanyak 29 responden $(53,7 \%)$.

Tabel 3. Distribusi frekuensi pengetahuan kesehatan gigi pada anak sekolah kelas IV dan V MIN 1 Kota Banjarmasin tahun 2018

\begin{tabular}{cccc}
\hline No & $\begin{array}{c}\text { Pengetahuan } \\
\text { Kesehatan Gigi }\end{array}$ & Frekuensi & $\%$ \\
\hline 1. & Baik & 28 & 52,8 \\
2. & Kurang & 25 & 47,2 \\
\hline & Total & 53 & 100,0 \\
\hline
\end{tabular}

Berdasarkan tabel 3 menunjukkan bahwa responden dengan pengetahuan baik sebanyak 28 responden $(52,8 \%)$ dan responden dengan pengetahuan kurang sebanyak 25 responden $(47,2 \%)$

Tabel 4. Distribusi frekuensi dan waktu sikat gigi pada anak sekolah kelas IV dan V MIN 1 Kota Banjarmasin tahun 2018

\begin{tabular}{cccc}
\hline No & $\begin{array}{c}\text { Frekuensi dan } \\
\text { Waktu Sikat Gigi }\end{array}$ & Frekuensi & (\%) \\
\hline 1. & Baik & 29 & 54,7 \\
2. & Kurang & 24 & 45,3 \\
\hline & Total & 53 & 100,0 \\
\hline
\end{tabular}

Berdasarkan tabel 4 menunjukkan bahwa responden frekuensi dan sikat gigi yang baik sebanyak 29 responden $(54,7 \%)$ dan responden frekuensi dan sikat gigi yang kurang sebanyak 24 responden $(45,3 \%)$.

Tabel 5. Distribusi frekuensi makan-makanan kariogenik pada anak sekolah kelas IV dan V MIN 1 Kota Banjarmasin tahun 2018

\begin{tabular}{cccc}
\hline No & $\begin{array}{c}\text { Makan- } \\
\text { makanan } \\
\text { Kariogenik }\end{array}$ & Frekuensi & (\%) \\
\hline 1. & $\begin{array}{c}\text { Tidak suka } \\
\text { makanan manis } \\
\text { dan melekat }\end{array}$ & 24 & 45,3 \\
2. $\begin{array}{c}\text { Suka makanan } \\
\text { manis dan } \\
\text { melekat }\end{array}$ & 29 & 54,7 \\
\hline & & \\
\hline Total & 53 & 100,0 \\
\hline
\end{tabular}

Berdasarkan tabel 5 menunjukkan bahwa terdapat 24 responden (45,3\%) yang tidak suka mengkonsumsi makanan manis dan melekat dan terdapat 29 responden (54,7\%) yang suka makanan manis dan melekat.

Tabel 6. Distribusi frekuensi cara sikat gigi pada anak sekolah kelas IV dan V MIN 1 Kota Banjarmasin tahun 2018

\begin{tabular}{cccc}
\hline No & Cara Sikat Gigi & Frekuensi & $(\%)$ \\
\hline $\mathbf{1 .}$ & Baik & 20 & 37,7 \\
2. & Kurang & 33 & 62,3 \\
\hline & Total & 53 & 100,0 \\
\hline
\end{tabular}

Berdasarkan tabel 6 dapat diketahui bahwa sebanyak 20 responden (37,7\%) melakukan cara sikat gigi yang benar atau sesuai dengan yang dianjurkan dan 33 responden $(62,3 \%)$ melakukan cara sikat gigi yang kurang sesuai dengan yang dianjurkan.

Tabel 7. Distribusi frekuensi status karies gigi pada anak sekolah kelas IV dan V MIN 1 Kota Banjarmasin tahun 2018

\begin{tabular}{cccc}
\hline No & $\begin{array}{c}\text { Status } \\
\text { Karies Gigi }\end{array}$ & Frekuensi & (\%) \\
\hline 1. & Karies & 26 & 49,0 \\
2. & Tidak Karies & 27 & 51.0 \\
\hline & Total & 53 & 100,0 \\
\hline
\end{tabular}

Berdasarkan tabel 7 terdapat 26 responden $(49,0 \%)$ yang mempunyai karies gigi dan 27 responden $(51,0 \%)$ yang tidak mengalami karies gigi. 
Tabel 8. Distribusi responden menurut hubungan pengetahuan dengan status karies gigi pada anak sekolah MIN 1 Kota Banjarmasin tahun 2018

\begin{tabular}{|c|c|c|c|c|c|c|c|}
\hline \multirow{3}{*}{$\begin{array}{l}\text { Penget } \\
\text { ahuan } \\
\text { Keseh } \\
\text { atan } \\
\text { Gigi }\end{array}$} & \multicolumn{4}{|c|}{$\begin{array}{c}\text { Status Karies } \\
\text { Gigi }\end{array}$} & \multirow{2}{*}{\multicolumn{2}{|c|}{ Total }} & \multirow{3}{*}{$\begin{array}{c}\text { OR } \\
(95 \% \\
\mathrm{Cl})\end{array}$} \\
\hline & \multicolumn{2}{|c|}{$\mathrm{Ya}$} & \multicolumn{2}{|c|}{ Tidak } & & & \\
\hline & $\mathrm{N}$ & $\%$ & $\mathrm{~N}$ & $\%$ & $\mathrm{~N}$ & $\%$ & \\
\hline Kurang & 18 & 72,0 & 7 & $\begin{array}{l}28 \\
, 0\end{array}$ & 25 & $\begin{array}{c}100 \\
0\end{array}$ & $\begin{array}{l}6,429 \\
1,941\end{array}$ \\
\hline Baik & 8 & 28,6 & 20 & $\begin{array}{r}71 \\
, 4\end{array}$ & 28 & $\begin{array}{c}100 \\
0\end{array}$ & $\begin{array}{c}21,29 \\
4\end{array}$ \\
\hline Total & 26 & 49,1 & 27 & $\begin{array}{r}50 \\
, 9\end{array}$ & 53 & $\begin{array}{c}100 \\
, 0\end{array}$ & \\
\hline \multicolumn{8}{|c|}{ P Value =0,004 } \\
\hline
\end{tabular}

Berdasarkan tabel 8 analisis bivariat diketahui bahwa hubungan antara pengetahuan kesehatan gigi kurang dengan status karies gigi terdapat 18 responden $(72,0 \%)$ dan hubungan antara pengetahuan kesehatan gigi baik mempunyai karies gigi terdapat 8 responden (28,6\%). Hasil uji statistik diperoleh nilai $p$-value : 0,004 yang berarti nilai $p<0,05$.

Tabel 9. Distribusi responden menurut hubungan frekuensi dan waktu sikat gigi dengan status karies gigi pada anak sekolah MIN 1 Kota Banjarmasin tahun 2018

\begin{tabular}{|c|c|c|c|c|c|c|c|}
\hline \multirow{3}{*}{$\begin{array}{l}\text { Frekue } \\
\text { nsi } \\
\text { dan } \\
\text { Waktu } \\
\text { Sikat } \\
\text { Gigi } \\
\end{array}$} & \multicolumn{4}{|c|}{ Status Karies Gigi } & \multirow{2}{*}{\multicolumn{2}{|c|}{ Total }} & \multirow{3}{*}{$\begin{array}{c}\text { OR } \\
-(95 \% \\
\text { Cl) }\end{array}$} \\
\hline & \multicolumn{2}{|c|}{ Ya } & \multicolumn{2}{|c|}{ Tidak } & & & \\
\hline & $\mathrm{N}$ & $\%$ & $\mathrm{~N}$ & $\%$ & $\mathrm{~N}$ & $\%$ & \\
\hline Kurang & 18 & $\begin{array}{c}75, \\
0\end{array}$ & 6 & $\begin{array}{c}25, \\
0\end{array}$ & $\begin{array}{l}2 \\
4\end{array}$ & $\begin{array}{c}100 \\
, 0\end{array}$ & $\begin{array}{c}7,875 \\
2,298 \\
- \\
26,98 \\
5\end{array}$ \\
\hline Baik & 8 & $\begin{array}{c}27, \\
6\end{array}$ & 21 & $\begin{array}{c}72, \\
4\end{array}$ & $\begin{array}{l}2 \\
9 \\
\end{array}$ & $\begin{array}{c}100 \\
, 0\end{array}$ & \\
\hline Total & 26 & $\begin{array}{c}49, \\
1\end{array}$ & 27 & $\begin{array}{c}50 \\
9\end{array}$ & $\begin{array}{l}5 \\
3 \\
\end{array}$ & $\begin{array}{l}10 \\
0,0 \\
\end{array}$ & \\
\hline \multicolumn{8}{|c|}{$P$ Value $=0,002$} \\
\hline
\end{tabular}

Berdasarkan tabel 9 analisis bivariat diketahui bahwa hubungan antara frekuensi dan waktu sikat gigi dengan status karies gigi terdapat 18 responden $(75,0 \%)$ dan hubungan antara antara frekuensi dan waktu sikat gigi baik terdapat status karies gigi terdapat 8 responden (27,6\%). Hasil uji statistik diperoleh nilai $p$-value : 0,002 yang berarti nilai $p<0,05$.

Tabel 10. Distribusi responden menurut hubungan makan-makanan kariogenik dengan status karies gigi pada anak sekolah MIN 1 Kota Banjarmasin tahun 2018

\begin{tabular}{|c|c|c|c|c|c|c|c|}
\hline \multirow{3}{*}{$\begin{array}{l}\text { Makan- } \\
\text { makana } \\
\text { n } \\
\text { Karioge } \\
\text { nik }\end{array}$} & \multicolumn{4}{|c|}{ Status Karies Gigi } & \multirow{2}{*}{\multicolumn{2}{|c|}{ Total }} & \multirow{3}{*}{$\begin{array}{c}\text { OR } \\
(95 \% \\
\text { Cl) }\end{array}$} \\
\hline & \multicolumn{2}{|c|}{$\mathrm{Ya}$} & \multicolumn{2}{|c|}{ Tidak } & & & \\
\hline & $\mathrm{N}$ & $\%$ & $\mathrm{~N}$ & $\%$ & $\mathrm{~N}$ & $\%$ & \\
\hline $\begin{array}{l}\text { Suka } \\
\text { makana } \\
\text { n manis } \\
\text { Tidak }\end{array}$ & 19 & 65,5 & 10 & 34,5 & 29 & $\begin{array}{c}100 \\
0\end{array}$ & $\begin{array}{c}4,614 \\
1,437 \\
-\end{array}$ \\
\hline $\begin{array}{l}\text { suka } \\
\text { makana } \\
n \text { manis }\end{array}$ & 7 & 29,2 & 17 & 70,8 & 24 & $\begin{array}{c}100 \\
0\end{array}$ & $\begin{array}{c}14,81 \\
7\end{array}$ \\
\hline Total & 26 & 49,1 & 27 & 50,9 & 53 & $\begin{array}{c}100 \\
, 0\end{array}$ & \\
\hline
\end{tabular}

Berdasarkan tabel 10 analisis bivariat diketahui bahwa sebagian besar responden yang suka makanan manis dengan mempun yai status karies gigi sebanyak 19 responden $(65,5 \%)$ dan ada sebanyak 7 responden $(29,2 \%)$ responden yang tidak suka manis dengan mempunyai status karies gigi. Hasil uji statistik diperoleh nilai $p$-value : 0,018 yang berarti nilai $p<0,05$.

Tabel 11. Distribusi responden menurut hubungan cara sikat gigi dengan status karies gigi pada anak sekolah MIN 1 Kota Banjarmasin tahun 2018

\begin{tabular}{|c|c|c|c|c|c|c|c|}
\hline \multirow{3}{*}{$\begin{array}{l}\text { Cara } \\
\text { Sikat } \\
\text { Gigi }\end{array}$} & \multicolumn{4}{|c|}{$\begin{array}{c}\text { Status Karies } \\
\text { Gigi }\end{array}$} & \multirow{2}{*}{\multicolumn{2}{|c|}{ Total }} & \multirow{3}{*}{$\begin{array}{c}\text { OR } \\
(95 \% \\
\text { Cl) }\end{array}$} \\
\hline & \multicolumn{2}{|c|}{$\mathrm{Ya}$} & \multicolumn{2}{|c|}{ Tidak } & & & \\
\hline & $\mathrm{N}$ & $\%$ & $\mathrm{~N}$ & $\%$ & $\mathrm{~N}$ & $\%$ & \\
\hline Kurang & $\begin{array}{l}2 \\
1\end{array}$ & $\begin{array}{c}63 \\
6\end{array}$ & 12 & $\begin{array}{r}36 \\
, 4\end{array}$ & 33 & $\begin{array}{c}100 \\
0\end{array}$ & $\begin{array}{c}5,250 \\
1,526- \\
18,06 \\
8\end{array}$ \\
\hline Baik & 5 & $\begin{array}{l}25 \\
, 0 \\
\end{array}$ & 15 & $\begin{array}{l}75 \\
, 0\end{array}$ & 20 & $\begin{array}{c}100 \\
, 0\end{array}$ & \\
\hline Total & 26 & $\begin{array}{l}49 \\
1\end{array}$ & 27 & $\begin{array}{l}50 \\
, 9 \\
\end{array}$ & 53 & $\begin{array}{c}100 \\
, 0\end{array}$ & \\
\hline
\end{tabular}

Berdasarkan tabel 11 analisi bivariat menunjukkan bahwa terdapat 21 responden $(63,6 \%)$ dengan cara sikat gigi kurang terdapat status karies gigi dan terdapat 5 responden $(25,0 \%)$ dengan cara sikat gigi baik yang terdapat status 
karies gigi. Hasil uji statistik diperoleh nilai $p$-value : 0,015 yang berarti nilai $p<0,05$.

\section{Pembahasan}

Penelitian ini dilakukan pada 53 responden dengan karakteristik jenis kelamin, usia, dan kelas. Jumlah siswa laki-laki sebanyak 24 orang $(45,3 \%)$ dan siswa perempuan sebanya 29 orang $(54,7 \%)$. Kelompok usia 9-10 tahun sebanyak 24 orang (45,3\%), dan 11-12 tahun sebanyak 29 orang $(54,7 \%)$. Karakteristik kelas dikelompok-kan berdasarkan kelas IV sebanyak 20 orang $(37,7 \%)$ dan kelas $\mathrm{V}$ sebanyak 33 orang $(62,3 \%)$.

Berdasarkan hasil pemeriksaan kuesioner pada parameter pengetahuan kesehatan gigi didapatkan sebanyak 28 responden $(52,8 \%)$ berpengetahuan baik dan 25 responden $(47,2 \%)$ berpengetahuan kurang.

Hasil uji chi square didapatkan nilai $p$-value 0,004 yang berarti nilai $p<0,05$ yang artinya ada hubungan yang signifikan antara pengetahuan kesehatan gigi dengan status karies gigi pada anak sekolah MIN 1 Kota Banjarmasin. Selanjutnya nilai Odds Ratio $(\mathrm{OR})=6,429$ artinya pengetahuan kesehatan gigi kurang memiliki resiko 6,43 kali terhadap karies gigi.

Sejalan dengan penelitian Hastuti (2010) mengungkapkan bahwa status kesehatan gigi dan mulut seseorang dipengaruhi oleh seberapa tinggi pengetahuan tentang kesehatan gigi dan mulut (10). Selain itu juga penelitian yang dilakukan oleh Norfai dan Eddy Rahman dimana dalam penelitiannya diperoleh hasil bahwa ada hubungan yang bermakna antara pengetahuan dengan karies gigi $p$-value 0,014 (11).

Pengetahuan yang baik apabila tidak ditunjang dengan sikap positif yang diperlihatkan akan mempengaruhi seseorang dalam berperilaku, seperti yang diungkapkan oleh Bloom dalam Notoadmojo (2010) yang menyatakan bahwa domain dari perilaku adalah pengetahuan, sikap dan tindakan (12).

Kebiasaan membersihkan gigi dan mulut sebagai bentuk perilaku yang didasari oleh pengetahuan akan mempengaruhi baik atau buruknya kebersihan gigi dan mulut, maka juga akan mempengaruhi angka karies gigi.

Berdasarkan pemeriksaan kuesioner pada parameter frekuensi dan waktu sikat gigi didapatkan sebanyak 29 responden $(54,7 \%)$ frekuensi dan waktu sikat giginya baik dan sebanyak 24 responden (45,3\%) frekuensi dan waktu sikat giginya kurang.

Hasil uji chi square didapatkan nilai $p$-value 0,002 yang berarti nilai $p<0,05$ yang artinya ada hubungan yang signifikan antara frekuensi dan waktu sikat gigi dengan status karies gigi pada anak sekolah MIN 1 Kota Banjarmasin. Selanjutnya nilai Odds Ratio $(\mathrm{OR})=7,875$ artinya frekuensi dan waktu sikat gigi kurang memiliki resiko 7,87 kali terhadap karies gigi.

Frekuensi menyikat gigi adalah 3 kali sehari, namun 2 kali seharipun sudah cukup yaitu setelah makan pagi dan sebelum tidur (13). Waktu menggosok gigi yang baik adalah pagi setelah makan dan malam sebelum tidur. menggosok gigi setelah makan baik dilakukan agar sisa makanan yang dimakan tidak menempel di gigi. Menggosok gigi sebelum tidur sangat penting karena saat tidur terjadi interaksi antara bakteri mulut dengan sisa makanan pada gigi (14).

Menurut hasil Riskesdas dalam Budisuari, dkk. anak yang menggosok gigi sesudah makan cenderung untuk terjadi karies rata-rata sebesar 0,957 kali dibandingkan dengan anak yang tidak menggosok gigi setelah makan (15).

Kebiasaan membersihkan gigi dan mulut sebagai bentuk perilaku yang didasari oleh pengetahuan akan mempengaruhi baik atau buruknya kebersihan gigi dan mulut, selanjutnya juga akan mempengaruhi angka karies (9).

Berdasarkan pemeriksaan kuesioner pada parameter makan-makanan kariogenik didapatkan sebanyak 24 responden $(45,3 \%)$ tidak suka makanan manis dan melekat dan sebanyak 29 responden $(54,7 \%)$ suka makanan manis dan melekat.

Hasil uji chi square didapatkan nilai $p$-value 0,018 yang berarti nilai $p<0,05$ yang artinya ada hubungan yang signifikan antara makan-makanan kariogenik dengan status karies gigi pada 
anak sekolah MIN 1 Kota Banjarmasin. Selanjutnya nilai Odds Ratio $(\mathrm{OR})=4,614$ artinya perilaku suka makan-makanan manis memiliki resiko 4,61 kali terhadap karies gigi.

Anak usia sekolah dasar merupakan salah satu kelompok yang rentan terhadap penyakit gigi terutama karies. Salah satu penyebabnya adalah tersedianya jenis jajanan anak-anak di lingkungan sekolah yang manis, lunak, dan melekat pada gigi, sehingga sangat merusak gigi seperti permen, coklat, biskuit. Apalagi bila kebersihan gigi dan mulut kurang (1). Konsumsi makanan manis pada waktu senggang diantara jam makan akan lebih berbahaya daripada saat waktu makan utama (16).

Sejalan dengan penelitian Khusnul Kotimah (2012), didapatkan hasil penelitian menunjukkan bahwa konsumsi makanan kariogenik responden sebagian besar sering mengkonsumsi makanan kariogenik sebanyak 35 responden (50\%), sedangkan yang jarang mengkonsumsi makanan kariogenik sebanyak 33 responden $(47,1 \%)$ dan yang tidak pernah mengkonsumsi makanan kariogenik sebanyak 2 responden (2,9\%). Hasil uji statistk didapatkan nilai $p=0,017$, yang artinya ada hubungan yang bermakna antara makanan kariogenik dengan kejadian karies gigi (17).

Begitu juga penelitian Meisihi (2011) di Medan yang menunujukkan bahwa banyak responden yang mengkonsumsi jajanan berpotensi tinggi dan sedang menyebabkan karies. Umunya jajanan yang berpotensi tinggi menyebabkan karies seperti permen, cokelat, keripik, kue, biskuit, wafer dan jajanan berpotensi sedang menyebabkan karies seperti minuman manis, bakso, kerupuk, dan goreng-gorengan (18).

Mengonsumsi makanan ringan yang bersifat kariogenik dan asidogenik 3 kali sehari atau lebih dalam jangka waktu yang lama dapat meningkatkan risiko karies. Gula dalam makanan ringan dapat menurunkan $\mathrm{pH}$ di dalam plak, jika semakin tinggi frekuensi konsumsi makanan ringan yang bersifat kariogenik dan asidogenik maka semakin tinggi penurunan $\mathrm{pH}$ di dalam plak 5,6. Kontrol plak dapat dilakukan dengan cara menggosok gigi menggunakan pasta gigi yang mengandung fluoride minimal 2 kali sehari pada pagi dan malam hari (13).

Berdasarkan pemeriksaan kuesioner pada parameter cara sikat gigi didapatkan sebanyak 20 responden $(37,7 \%)$ cara sikat gigi baik dan sebanyak 33 responden $(62,3 \%)$ cara sikat gigi kurang.

Hasil uji chi suare didapatkan nilai $p$ value 0,015 yang berarti nilai $p<0,05$ yang artinya ada hubungan yang signifikan antara cara sikat gigi dengan status karies gigi pada anak sekolah MIN 1 Kota Banjarmasin. Selanjutnya nilai Odds Ratio $(O R)=5,250$ artinya perilaku cara sikat gigi kurang memiliki resiko 5,25 kali terhadap karies gigi.

Perawatan gigi yang baik penting diajarkan dan diterapkan selama masa usia sekolah, hal ini dikarenakan gigi permanen yang muncul selama periode usia sekolah membutuhkan kebersihan gigi yang baik dan perhatian yang rutin terhadap adanya karies gigi, selain itu periode usia sekolah merupakan periode yang tepat untuk menerima latihan perilaku dan kesehatan (19).

Sejalan dengan penelitian Rizky Ananda Putri (20) dimana dalam penelitian ini diperoleh hasil bahwa terdapat hubungan cara menggosok gigi $(P=0,000)$ dengan kejadian karies gigi. Selain itu juga penelitian Desti Junarti diperoleh hasil ada hubungan antara cara sikat gigi $(p$-value $=0,006)$ dengan status karies gigi (21).

Berbagai penelitian telah dilakukan terkait teknik menggosok gigi yang tepat. Namun tidak terdapat bukti bahwa teknik yang satu lebih baik dari teknik yang lain dalam menghilangkan plak gigi (14).

Menggosok gigi adalah rutinitas yang penting dalam menjaga dan membersihkan gigi. Keterampilan menggosok gigi harus diajarkan dan diterapkan pada anak segala usia terutama usia anak sekolah karena usia itu mudah menerima dan menanamkan nilai-nilai dasar. Anak sekolah memerlukan pembelajaran untuk meningkatkan keterampilan menggosok gigi. 


\section{Kesimpulan}

1. Ada hubungan yang signifikan antara pengetahuan kesehatan gigi dengan status karies gigi dengan $p$-value 0,004 .

2. Ada hubungan yang signifikan antara perilaku pemeliharaan kesehatan gigi dengan status karies gigi yaitu, (frekuensi dan waktu sikat gigi $p$ value 0,002 , makan-makanan kariogenik $p$ value 0,018 , cara sikat gigi $p$ value 0,015).

\section{Ucapan Terimaksih}

Kami mengucapkan terima kasih kepada Kepala Puskesmas Kelayan Timur dan Perawat Gigi, Kepala Sekolah MIN 1 Kota Banjarmasin dan muridnya sebagai responden, dan dosen dan mahasiswa yang banyak memberikan bantuan dan masukan dalam penelitian ini.

\section{Daftar Pustaka}

1. Sariningsih E. Merawat Gigi Anak Sejak Usi Dini, Jakarta: PT Elex Media Komputindo; 2012

2. Kementrian Kesehatan RI. InfoDantin, Situasi Kesehatan Gigi dan Mulut. 2014

3. World Health Organization; 2009. Milk fluoridation for the prevention of dental caries

4. World Health Organization. Oral health;2012 [Cited 22 April 2018]. Available from: http://www.who.int/oral_health/publica tions/factsheet/en/

5. Depkes RI. Pedoman Upaya Kesehatan Gigi Masyarakat, Cetakan Ketiga, Jakarta: Direktorat Jendral Pelayanan Medik; 2007

6. Kementrian Kesehatan RI. Riskesdas Dalam Angka Provensi Kalimantan Selatan; 2013

7. Nurafifah D. Hubungan Perilaku Pencegahan Karies Gigi Dan Kejadian karies Gigi Pada Anak Di Dusun Sumberpanggang Desa Lopang Kecamatan Kembangbahu kabupaten Lamongan. Jurnal Vol.01, Edisi XIV, 2013, Hal. 51-57: Sekolah Tinggi IImu Kesehatan Muhammadiyah Lamongan.
8. Notoatmodjo, S. Promosi Kesehatan \& IImu Perilaku. Jakarta : Rineke Cipta; 2007

9. Astoeti TE. Total Quality Management Dalam Pendidikan Kesehatan Gigi di Sekolah, Jakarta: PT. Raja Grafindo Persada; 2006

10. Hastuti S., dan Andriyani A. Perbedaan pengaruh pendidikan kesehatan gigi dalam meningkatkan pengetahuan tentang kesehatan gigi pada anak di SD Negeri 2 Sambi Kecamatan Sambi Kabupaten Boyolali. Jurnal Volume 7, Edisi 2, 2010, Hal 625-632: Sekolah Tinggi IImu Kesehatan Aisyiyah Surakarta

11. Norfai dan Rahman E. Hubungan Pengetahuan dan Kebiasaan Menggosok Gigi Dengan Kejadian Karies Gigi Di SDI Darul Mu'minin Kota Banjarmasin. Jurnal Vol.8, Edisi 1, 2017, hal 212-218: Universitas Islam Kalimantan

12. Notoadmojo S. Promosi Kesehatan Teori \& Aplikasi. Jakarta: Rineke Cipta; 2010

13. Djamil MS. A-Z Kesehatan Gigi Panduan Lengkap Kesehatan Gigi Keluarga, Solo: PT Tiga Serangkai Pustaka Mandiri; 2011

14. Dewanti. Hubungan Tingkat Pengetahuan Tentang Kesehatan Gigi Dengan Peilaku Perawatan Gigi Pada Anak Usia Sekolah Di SDN Pondok Cina 4 Depok. [Skripsi]: Universitas Indonesia; 2011

15. Budisuari MA, et al. Hubungan Pola Makan dan Kebiasaan Menyikat Gigi dengan Kesehatan Gigi dan Mulut (Karies) di Indonesia. Buletin Penelitian Sistem; 2010

16. Anggraeni DK. Hubungan Antara Tingkat Konsumsi Karbohidrat Dan Frekuensi Makan Makanan Kariogenik dengan kejadian Penyakit karies Gigi Pada Anak Pra Sekolah Di TK ABA 52 Semarang. [Skripsi]: Universitas Negeri Semarang; 2007

17. Khusnul Khotimah. Faktor-Faktor yang Berhubungan Dengan Kejadian Karies Gigi Pada Anak Usia 6-12 Tahun di Sd Negeri Karangayu 03 Semarang. Jurnal Volume 1, 2012, Edisi 3, Hal 10-20: STIKES Tologorejo Semarang 
18. Meishi PRL. Hubungan Tingkat Konsumsi Makanan Kariogenik Dengan Karies Gigi Pada Anak Sekolah Dasar Swasta Muhammadiyah 08 Medan. [Skripsi]: Universitas Sumatra Utara. 2011

19. Potter, P.A. and Perry, A.G. Buku Ajar Fundamental Keperawatan: Konsep, Proses, dan Praktik. Edisi 4, Volume 1, Alih Bahasa, Asih, Y., dkk. EGC, Jakarta; 2005

20. Junarti D.. Hubungan Perilaku Pemeliharaan Kesehatan Gigi Dengan Status Karies. [Skripsi]: Universitas Negeri Semarang; 2015 